\title{
BUSINESS STRATEGIES UNDER THE NEW MARKETING MYOPIA PERSPECTIVE
}

ESTRATÉGIAS DE NEGÓCIO SOB O ENFOQUE DA NOVA MIOPIA EM MARKETING

Recebido em 01.02.2021 Aprovado em 20.05.2021

Avaliado pelo sistema double blind review

DOI: https://doi.org/10.12712/rpca.v15i1.48604

\begin{abstract}
Ana Tereza Freitas Delapedra
anadelapedra@hotmail.com

Mestrado Acadêmico em Administração de Empresas/FGV EAESP - São Paulo/São Paulo, Brasil

https://orcid.org/0000-0002-1886-4849
\end{abstract}

\section{Juliano Domingues da Silva}

jdsilva2@uem.br

Programa de Pós-Graduação em Administração/Universidade Estadual de Maringá - Maringá/Paraná, Brasil

https://orcid.org/0000-0001-7599-0617

\begin{abstract}
The new marketing myopia portrays companies that focus excessively on the customer, neglecting other stakeholders' demands that can transform the market and lead companies to failure. Although this discussion is present in marketing literature, researchers and marketers miss trails to identify new marketing myopia. This study aims to analyze business strategies under the new marketing myopia perspective. Qualitative and descriptive research was undertaken through a multiple case study of five South American companies acknowledge by Forbes for the customer orientation. This study demonstrates the companies' difficulty to equilibrate customers and other stakeholders' demands to define their business strategies.
\end{abstract}

Keywords: Marketing myopia. Stakeholders. Scope. Mission. Vision.

\section{Resumo}

A nova miopia em marketing retrata empresas com ênfase excessiva no cliente, desconsiderando demandas de outros stakeholders que transformam o mercado e levam as empresas à falência. Embora essa discussão exista na literatura de marketing, pesquisadores e profissionais carecem de trilhas para identificar a nova miopia em marketing. Este estudo analisa estratégias de negócios sob a perspectiva da nova miopia em marketing. Realizou-se um estudo de casos múltiplos de empresas sul-americanas reconhecidas pela Forbes por sua orientação para o cliente. Os resultados mostram a dificuldade de as empresas equilibrarem as demandas dos clientes e stakeholders considerando suas estratégias de negócio. Palavras-chave: Miopia em marketing. Stakeholders. Escopo. Missão. Visão. 


\section{Introduction}

Levitt's (1960) research about the marketing myopia represented an expressive evolution to the marketing science. This prestigious was recognized with the McKinsey Award in 1960 and, in 2004, the Harvard Business Review republished his paper "The marketing myopia" as "the most influential marketing idea of the past half-century" (Levitt, 2004). Levitt's ideas were revolutionary for that time, shifting the marketers' attitudes. Nowadays, fifty years after the paper's publication, the marketers do a better job focusing on the customers' needs (Smith, Drumwright, \& Gentille, 2010).

The influence of Levitt's (1960) paper seems to have improved the lenses of marketers for focusing on the customers. However, it blurred attention to other agents that also affect the organization and its relationship with customers, the named stakeholders (Freeman \& Reed, 1983). Smith et al. (2010) propose that the lack of strategic orientation towards stakeholders comprises a new form of myopia in marketing. Through this novel concept of marketing myopia, the marketers cannot comprehend the broader social context of decision making, entailing catastrophic results for their organizations and society (Smith et al., 2010).

The new marketing myopia discussion influenced research that recognized the relevance of the stakeholder's orientation (e.g., Hillebrand, Driessen, \& Koll, 2015; Kull, Mena, \& Korschun, 2016; Brennan, Previte, \& Fry, 2016). However, after one decade since the beginning of the discussion, the marketers have not learned the new lesson yet. For example, to offer varied meals that please customers' taste, fast-food chains provide less balanced menus than 30 years ago (McCrory, Harbaugh, Appeadu, \& Roberts, 2019), even in the face of the global obesity problem. Moreover, there is the case of excessive use of agrochemicals in the food industry to improve the aesthetic attributes of products and meet customer demands for a pleasing appearance on the supermarket shelf.

In the two cases, the customers' needs are promptly met by the companies. However, several stakeholders are negatively impacted in the process, such as workers who handle the agrochemicals, the health of individuals in the long term, public institutions dealing with public health. This myopia of not comprehending the needs of all agents involved may lead these companies to be replaced by others that are not myopic in marketing. The organic food segment, for example, can be a potential substitute. According to the International Federation of Organic Agriculture Movements (IFOAM), in 2016, 57.8 million hectares dedicated to organic food production were registered worldwide, in 178 countries (Golijan \& Dimitrijević, 2018). Although organic foods are not aesthetically beautiful and do not arouse customers' desire, they are expanding the market share: when purchasing organic food, the customers consider the utilitarian attributes in addition to the hedonic attributes (Leen \&Yun, 2015).

To avoid new myopia in marketing, Smith et al. (2010) suggest that the companies' business strategy considers the customers, the stakeholders, and the demands of both. The business strategy covers the scope of action, the strategic orientation, and the relationship with the environment. In the present work, through the qualitative investigation of five cases of South American companies recognized for their excellence in customer orientation (Forbes, 2018), we seek to analyze business strategies from the perspective of new myopia in marketing.

The results of this work offer two contributions. First, this paper expands the discussion initiated by Smith et al. (2010) by offering tangible elements observed in the companies' business strategies that may lead or prevent new myopia in marketing. These elements can help future researchers to identify the new myopia in marketing and relate it to marketing results. Second, this work provides trails for marketers to recognize their actions under the rationale of new myopia in marketing. 


\section{Theoretical background}

\section{The marketing myopia}

The term "myopia in marketing" was first used by Theodore Levitt, in 1960, in his article published in Harvard Business Review. Levitt (1960) stated that the decline of growing companies was not due to market saturation but to management failures.

According to Levitt (1960), the failures in these companies' management occurred due to addressing business efforts towards improving products, neglecting customers' needs. To elucidate this proposition, the author presents examples of industries that had their growth interrupted by the lack of focus on the customer, such as the railway industry and Hollywood studios. According to Levitt (1960), such companies sought to improve their products incessantly, not paying attention to the fact that their customers' needs were changing. Due to this flaw in companies' orientation, the railway industry did not realize that it was inserted in the transport market (and not in trains), being replaced by automobiles. Moreover, the Hollywood studios did not realize that they were inserted in the entertainment market (and not of films), losing space for television (Levitt, 1960).

Urdan and Rocha (2006) synthesize the concept of myopia in marketing in the notion that failure occurs when companies do not understand customers' expectations and needs and how product diversification occurs overtime to meet those needs.

Levitt's (1960) text was not limited to exposing the industries' mistakes and highlighted the good practices of organizations oriented to customers. Thus, Levitt (1960) presented examples of the nylon, glass, and aluminum industries, which have always been rising. These industries' success is justified by efforts to satisfy customers' needs, even after the most obvious market opportunities have been exhausted (Levitt, 1960).

Declining companies from that time had a strict view of the business in which they were inserted, as well as the products they offered, being victimized by the phenomenon of obsolescence (Levitt, 1960). Levitt (1960) argued that these companies adhered to an apparent indisputable superiority of the product, for which there were no apparent substitutes. Despite this comprehension, it is common for companies to resist the scenario of volatility and intense competition in which they are inserted (Ceribeli, Maciel, \& Guilarducci, 2017). Although understanding change is a more relaxed way of dealing with environmental changes, organizations tend to ignore it (Ciccarino \& Araki, 2017).

There were no growing companies for Levitt (1960), only companies oriented to create and seize growth opportunities. Companies that were relying on the belief in automatic growth were fated to stagnation and decline, being at the mercy of what Levitt (1960) called the self-delusion cycle, composed of four conditions:

(1) The belief that growth is assured by an expanding and more affluent population. (2) The belief that there is no competitive substitute for the industry's major product. (3) Too much faith in mass production and in the advantages of rapidly declining unit costs as output rises. (4) Preoccupation with a product that lends itself to carefully controlled scientific experimentation, improvement, and manufacturing cost reduction (Levitt, 1960, p. 63).

According to Levitt (1960), these practices lead the company to the philosophy of "courage of its convictions": the assumption that its growth is imminent, with no need for actions that prioritize the organization's development. Both individuals and companies tend to stick to their convictions, neglecting that the dynamic balance between forces is transitory (Ciccarino \& Araki, 2017). 
In this sense, Levitt (1960) alerts managers from that time to the inherent risk of product obsolescence: entrepreneurs needed to be aware that, if they did not premeditate product obsolescence, another company would do so, presenting a substitute product to the market. According to Pereira, Schmitt, and Caldas (2006), myopic companies' management lacked creativity, audacity, and focus for an external view of the organization, which made it difficult to identify market opportunities, as well as the needs of their customers.

In general, according to Levitt (1960), the company needed to understand itself as a buyer of customers and not a producer of goods and services, expressing the need for full customer orientation. For Levitt (1960), the "myopia in marketing" was represented by the companies' strategic vision failure, which was oriented to the product and not to the customers' needs.

\section{The new marketing myopia: updating concepts}

These ideas of prioritizing the customers above all the other stakeholders were strongly disseminated among marketers, promoting the marketing area as the most important in the organizations (Oliveira \& Luce, 2020). According to Kunkel et al. (2012), inspired by successful companies' cases in understanding consumers' needs, organizations started to be oriented to customers' desires and satisfaction, consolidating the concepts of current marketing. Moreover, the increase in competition in recent decades - driven by the opening of the national market and the economy's growth - contributed significantly to customer satisfaction became the focus of the companies' marketing strategy (Kunkel et al., 2012).

However, Smith et al. (2010) argue that marketers learned Levitt's lesson in focusing on the customer so exemplarily that they enabled the emergence of a new form of myopia in marketing, which can distort the strategic vision of companies, leading them to ruined or marginalizing the role of marketing.

It is appropriate that myopia's marketing concept has changed over the years, representing the evolution and improvement of the concept and marketing practices. After Levitt's studies in the '60s, myopia's marketing concept was rescued from being analyzed again by Smith et al. (2010) from the current market perspective. According to the authors, "the new marketing myopia occurs when marketers are unable to see the broader social context of business decision, sometimes with disastrous results for their organizations and society" (Smith et al., p. 4, 2010). Under the blurred perspective of new myopia in marketing, companies confuse the concept of marketing, acting to create goods and services aimed at generating economic profit, neglecting stakeholders' demands for products that generate long-term social impact (Bernal 2011; Yenicioglu \& Suerdem, 2015).

In this context, the new marketing myopia is based on three interrelated phenomena: "(1) a single-minded focus on the customer to the exclusion of other stakeholders, (2) an overly narrow definition of the customer and his or her needs, and (3) a failure to recognize the changed societal context of business that necessitates addressing multiple stakeholders" (Smith et al., p. 4, 2010).

According to Freeman and Reed (1983), stakeholders are any group or individual that can affect or is affected by the company's objectives. The relationship with stakeholders is fundamental for the survival of the company today (Smith et al., 2010). Therefore, the company's fundamental role is to identify its key stakeholders and classify them according to the interests demanded (Kumar, Rahman, \& Kazmi, 2016).

According to Smith et al. (2010), current companies relegate stakeholders' performance, having a central focus only on the customer and their needs. Thus, companies place customers at the center of marketing activities, observing them in a shallow perspective, aiming exclusively to capture their needs. From that, the company can create products that deliver value to them. This mistaken focus leads consumers to feel victims of companies, having their needs objectified so that industries can satisfy them in the short term through the massive creation of goods or services (Bernal, 2017). However, the social role played by the 
client is almost always relegated by the analysis of marketers: it is necessary to understand that the individual, in addition to being a customer, also plays the role of "a citizen, a partner, an employee, a community member, or a member of a global village with a long-term in stake in the future of the planet" (Smith et al., p. 4, 2010).

Therefore, it is necessary to consider the set of stakeholders concerned with the company's social and environmental impacts, incorporating these efforts at a strategic level (Smith et al., 2010; Campos \& Pedroso, 2015). In this sense, consumers are increasingly concerned about the impacts generated by consumption, considering not exclusively their basic needs but ethical and environmental issues in their purchases (Prado \& Moraes, 2020).

According to Bernal (2017), current companies need to consider that the market comprises stakeholders who identify offers that are not harmful to individuals or organizations. It is necessary to recognize that these stakeholders bring intrinsic social forces that have changed the social context and decision-making in the management environment over the past few years (Smith et al., 2010). For this reason, stakeholders deserve greater attention from marketers, demanding that the company recognize its role in society, migrating the narrow focus on customers to a stakeholder orientation (Smith et al., 2010). The company's negligence in observing stakeholders can easily lead to business failure (Lyra, Gomes, \& Jacovine, 2009).

Stakeholder orientation is not always a straightforward task for the company. It is often necessary to engage with groups that marketers see as adversaries, such as activists, scientists, politicians, and the local community (Smith et al., 2010). Although the relationship with this type of stakeholder seems complex, it allows several benefits for the organization since stakeholders can potentially help marketers develop predictions about the futures markets, promoting the impetus for innovation (Smith et al., 2010).

To exemplify a situation in which the new marketing myopia is present, Smith et al. (2010) cite, among other cases, the obesity crisis in the United States. According to the authors, for many years, food and fast-food manufacturers serving children have focused only on satisfying children's short-term appetites, without thinking about customers' long-term well-being; the opinions of other stakeholders (such as the parents of the children) concerned with the children's nutrition were left out (Smith et al., 2010). After the explosion of the obesity crisis, these companies surrendered and had to adopt restrictions in child marketing; it was too late, as these companies had already taken all the blame for the obesity crisis (Smith et al., 2010). According to the authors, if companies had anticipated and collaborated with stakeholders in this process, they might not have had to bear all this blame (Smith et al., 2010).

This resistance to accept the role of stakeholder impact for the organization is similar to the stubbornness present in the "original" myopia in marketing in assuming the changing business environment. Levitt (1960) cites in his text the misleading conviction of grocery stores from that time to accept the emergence of supermarkets: merchants refused to believe that consumers would go to move for better prices and, in the end, found themselves in the face of the failure of its devastated companies. The same occurs with the new marketing myopia. Companies are reluctant to accept stakeholders' impact (especially those seen as enemies) on their customers' behavior and the company, preferring to ignore these agents.

As an alternative to the new marketing myopia, Bernal (2017) proposes that companies recognize the long-term impact they can generate on consumers and the society in which they are inserted. Moreover, it is necessary to get closer to customers, considering their real needs when creating new products (Oliveira \& Luce, 2020). It is also essential to consider the positions of the external parties to the producer-consumer exchange relationship so that the impact generated on both the consumer and the community is the least harmful possible and that the good or service meets the consumer's needs in the short and long term. 
Seeking to solve and avoid the new marketing myopia, Smith et al. (2010) present practical propositions based on the literature on stakeholder management, as well as on research about stakeholders in marketing: (1) Map the company's stakeholders; (2) Determine the stakeholder relevance; (3) Investigate stakeholder problems and expectations and measure impact; (4) Engage with stakeholders; (5) Adopt a stakeholder orientation.

To sum up, Smith et al. (2010) emphasize a more sophisticated understanding of consumption that considers the demands of stakeholders as a whole, without neglecting customers' needs.

\section{Methodology}

This research has a qualitative and descriptive approach. As a research strategy, we adopted the multiple cases study, considering that several companies' analysis provides complementary information on the theme (Yin, 2005). The criterion used for selecting the companies analyzed was due to the publication by Forbes (2018) of the nine South American companies most focused on the customer. Companies known to be customer-oriented provide cases rich in information to analyze the elements that may present new myopia in marketing since their actions can expose an excessive focus on the customer to the detriment of other agents of society.

The list published by Forbes (2018) presents the following companies: (1) Arcos Dorados; (2) Santander; (3) Pharmacorp; (4) Concentrix Brasil; (5) Magazine Luiza; (6) Aira; (7) Conta Azul; (8) Sambatech; (9) Produbanco. The data collection considered the investigating companies' institutional websites, aiming to verify, among other aspects, the mission, the vision, the values, and the attitudes towards the companies' organizational environment. The companies Concentrix Brasil, Aira, Conta Azul, and Sambatech were excluded from the sample. They did not present the elements required for analysis in their institutional portals, totalizing five companies for analysis.

The data analysis was conducted to meet the analysis categories composed of the analysis elements, as demonstrated in the following Table 1.

Table 1 - Analysis categories and elements of analysis

\begin{tabular}{|c|c|}
\hline Analysis categories & Elements of Analysis \\
\hline 1. Scope of action & $\begin{array}{l}\text { (i) Definition of the products and the products' attributes (Levitt, 1960) } \\
\text { (ii) Definition of the customers and their needs (Levitt, 1960) } \\
\text { (iii) Definition of customers, stakeholders, and the needs of both (Smith et al., 2010) }\end{array}$ \\
\hline $\begin{array}{l}\text { 2. Strategic } \\
\text { orientation }\end{array}$ & $\begin{array}{l}\text { (i) Focus on the product (Levitt, 1960) } \\
\text { (ii) Focus on the customers (Levitt, 1960) } \\
\text { (iii) Focus on the customers and stakeholders (Smith et al., 2010) }\end{array}$ \\
\hline $\begin{array}{l}\text { 3. Relationship with the } \\
\text { organizational } \\
\text { environment }\end{array}$ & $\begin{array}{l}\text { (i) Concern for customers (Levitt, 1960) } \\
\text { (ii) Concern with the market (Levitt, 1960) } \\
\text { (iii) Concern for multiple stakeholders (Smith et al., 2010) }\end{array}$ \\
\hline
\end{tabular}

Source: Authors

Each analysis category was based on specific items of the companies' strategic planning in order to investigate the elements of the business strategy and classify the different categories as myopic or not. This analysis is based on the fact that strategic planning denotes how the company operates in the market and expresses the parameters that guide the organization of the company (Andion \& Fava, 2002).

The (1) Scope of action was analyzed according to the organizations' mission on their institutional websites. According to David (2009), the company's mission must encompass, besides the organization's reason for existence, essential elements, such as the main products and services offered; the intended target markets; the company's concern with growth, efficiency, employees, shareholders, the environment and long-term profitability. Based on this, in the analysis of the Scope of Action, we sought to identify: 
(a) definition of the company's products and their attributes; (b) definition of customers and their needs;

(c) definition of customers, stakeholders, and the needs of both.

In turn, the (2) Strategic orientation was analyzed based on the vision and values (or similar concepts) presented by the companies. The company's vision expresses its future aspirations, denoting how the company intends to be seen and what image it intends to show (Portella, Oliveira, Ferreira, \& Borba, 2015). In turn, values are the principles that guide the organization's activities in order to guide the decision-making process and the employees' behavior (Andrade \& Amboni, 2010). In this sense, to analyze the elements of the strategic orientation and identify elements of myopia in marketing, the following elements were observed in the companies' vision and values: (a) focus on the product; (b) focus on the customer; (c) focus on customer and stakeholders.

The companies' business strategies must also consider the information from the external environment (Pereira, 2019). In this sense, to analyze the (3) Relationship with the organizational environment, the companies' general aspects on their institutional websites were considered aiming to identify characteristics that denote myopia in marketing or not, such as the projects they carry out and/or the prizes obtained. To this end, we sought to identify: (a) concern for customers; (b) concern with the market; (c) concern for multiple stakeholders.

\section{Data analysis}

\section{Arcos Dorados}

Arcos Dorados is an independent franchise from McDonald's. It has been operating in eighteen countries in Latin America for ten years, with more than five thousand service units, including restaurants, McCafés, and dessert kiosks. Arcos Dorados' mission is "to serve quality food, generating delicious moments accessible for everyone." Analyzing the scope of action of Arcos Dorados through its mission, we note that the company has a clear definition of its products ("food") and their attributes ("quality"). In addition, the company's mission broadly defines the customers that the organization intends to serve (referring to them as "everyone"). Despite this definition of its customers, Arcos Dorados does not have in its mission a definition of the customers' needs. It only explains the experiences it seeks to provide ("generating delicious moments accessible for everyone"). From this company's intention, Arcos Dorados seems to create a need for customers to be served.

Based on the analysis of the scope of action, there is a tendency towards Levitt's (1960) myopia, since the organization defines only its products, explaining superficially about its customers and their needs. The mission also does not address other stakeholders, only customers. In this sense, it can be said that Arcos Dorados' scope of action also denotes a tendency to be affected by the Smith et al.'s (2010) new marketing myopia, given that it does not consider the other stakeholders, only the customers.

Moreover, to analyze the company's strategic orientation, we observed the vision presented by Arcos Dorados as "to be recognized for offering daily the best experience in each of our restaurants, generating value for our people and shareholders." This vision expresses a focus on the product, the customer, and other stakeholders (such as society and employees - "our people" and the shareholders). Therefore, this perspective does not characterize marketing myopia, indicating that its strategic orientation is not myopic.

The values presented on the website are:

(1) Deliver quality, service, and cleanliness to our customers. (2) We are result oriented with an entrepreneurial spirit. (3) We promote meritocracy and teamwork. (4) We value differences and foster inclusion. (5) We operate with responsibility and ethics. (6) We contribute to the communities' development. 
Based on these values, it is possible to detect in the company's vision a concern for other stakeholders besides customers, observing the company's awareness as a generator of social impacts. This fact exempts the company's strategic orientation from being classified as myopic.

Observing other aspects of the company to analyze its relationship with the organizational environment, there is a concern with the three elements of analysis: customers, market, and other stakeholders. Thus, there is a concern with the customer when seeking to meet their needs for quality of life, as shown in the restaurant menu's formulation: recently, restaurants modified the composition of a snack for children, composing it with fruit options. There is also a concern with the market when using vegetables from the local producers to promote local markets. The concern with other stakeholders is verified, for example, by sustainable practices adopted in the company's daily life - adherence to the UN Sustainable Development Goals, packaging from certified sources. Therefore, Arcos Dorados' relationship with the organizational environment denotes a marketing myopia-free.

\section{Santander}

Santander is a financial institution founded in 1857 in Spain. It is present in ten markets, both in Europe and in the Americas. The company focuses on the commercial bank, which is its primary source of revenue. In addition, Santander stands out as the top financial conglomerate in Latin America, occupying important positions in Brazil, Mexico, Argentina, and Chile.

The organization presents a purpose on the institutional website: "Contribute for people and businesses to prosper." Analyzing the scope of action through its purpose, we note that Santander operates in the B2C and B2B markets. However, the definition of customers is profuse. It does not define a specific target audience. In addition, Santander's purpose also does not define the products and their attributes. Thus, the purpose of the organization considers other stakeholders and customers, considering that it does not define the type of people and businesses to which it contributes.

Consequently, they are all considered, covering the company's stakeholders in addition to their customers. Therefore, Santander's scope of action is myopic according to Levitt's classification (1960). It does not present a clear definition of the products and their attributes. However, regarding the classification of the new marketing myopia by Smith et al. (2010), Santander's scope of action is exempt from this management flaw. It considers the performance of other stakeholders besides customers.

Although the institutional website does not present its vision, the core values of its business model were analyzed to verify its strategic orientation. In this regard, "Santander's business model is customeroriented, with a high level of recurrence in its results and revenues." Santander also presents its core values: "(1) Commercial approach; (2) Discipline in capital and financial strength; (3) Prudence in risks; (4) Geographic diversification; (5) Brand; (6) Efficiency". Santander's core values demonstrate a unique focus on the customer, with no concern for the product and other stakeholders. Thus, the strategic orientation of Santander is myopic according to the approach proposed by Levitt (1960), as well as new myopia in marketing proposed by Smith et al. (2010).

Furthermore, when investigating the relationship with the organizational environment, some attitudes of the company were observed, such as incentives to culture (promotion of local artists, preservation of the visual arts heritage); fostering various sectors (sports, education, etc.); commitment to the UN Sustainable Development Goals; commitment to ethics and sustainable development; carrying out the socioenvironmental risk analysis (socio-environmental criteria for client acceptance); commitment to reducing energy and paper consumption. These actions manifested on the website express the organization's concern for customers, the market, and multiple stakeholders. Thus, it is assumed that the relationship with the organizational environment does not denote any type of marketing myopia. 


\section{Farmacorp}

Farmacorp emerged in 2000 from a merger of pharmacy chains belonging to the grandchildren of one of the first pharmacists in the family. Currently, Farmacorp is recognized as one of the largest brands in the health industry in several cities in Bolivia, being one of the companies with the best reputation in the country.

The company's mission is presented on the institutional website:

We are Farmacorp, a team of committed and highly professional employees who, supported by constant innovation and advanced technology, work together to generate memorable experiences that help families lead a happy and healthy life.

Observing the scope of action, we note that Farmacorp does not clearly define its products and attributes. Moreover, the company defines the customers as "families" but does not define their needs: it only assumes that they work to make their lives healthy and happy. That is, they indicate the needs that they assume the customers have. The company's mission also does not consider the needs of other stakeholders. Thus, when observing the scope of action, we note aspects of marketing myopia according to Levitt's (1960) classification and Smith et al. (2010).

The company's website also presents Farmacorp's vision: "To be recognized globally as a model of success that contributes to people's daily well-being with the best customer service." The company's values, according to its institutional website, are: "(1) Spirit of overcoming; (2) Integrity; (3) Vocation of service - commitment; (4) Active listening". Thus, the strategic orientation suggests that the organization does not focus on the product or the stakeholders, only on the customer and the service. Therefore, the company's strategic orientation is classified as myopic.

Besides mission, vision, and values, the company's website does not present other information that can be analyzed to verify the relationship with the organizational environment.

\section{Magazine Luiza}

Magazine Luiza emerged in 1957, in the city of Franca - SP, founded by a couple who sold color TVs to customers in the region. Currently, the company is present in seventeen states in the country. It has twenty-two thousand employees and twelve distribution centers.

The institutional website states the mission: "To bring to many what is accessible to few". Based on Magazine Luiza's mission, we observe that the scope of action, although broad, has the definition of what products they offer and the customers that the company intends to serve. While this scope of action can be seen as broad, it can also be perceived as flexible since it is adapted to market changes. For example, when color TV was only accessible to a portion of the population, Magazine Luiza had the opportunity to serve those in the market that did not have access to this technology; the same occurred in the context of the appearance of the washing machine. Therefore, the scope of action does not fit as myopic according to Levitt's theory (1960). However, Magazine Luiza's scope of action does not consider the other stakeholders and their needs, being classified as myopic according to the Smith et al.'s (2010) approach.

The company's vision is not presented on the website with the term "vision". However, the company's purpose is identified:

Nowadays, we work to make connectivity accessible to as many Brazilians as possible. Making possible the purchase of smartphones, computers, and connected TVs is to contribute to digital inclusion. 
Although the company does not present its values on the website, the strategic orientation was analyzed based on its purpose. In this sense, it is noted that Magazine Luiza focuses on the customer and the product offered, which exempts the strategic orientation from the classification of myopic under Levitt's perspective (1960). However, the company's strategic orientation does not declare focus on other stakeholders, classifying it as myopic according to Smith et al. (2010) concepts.

When analyzing other aspects of the company, there are actions focused on environmental sustainability and society. To promote environmental sustainability, Magazine Luiza seeks partnerships with suppliers that respect ethical conduct and environmental legislation. The company also promotes the management of environmental impacts and the management of solid and recyclable waste. Moreover, social sustainability is provided through project management regarding culture, sports, education, and health. Therefore, we observe that Magazine Luiza considers the long-term customers' needs, seeing them not only as consumers. Thus, the relationship with the organizational environment is concerned with customers, the market, and other stakeholders and cannot be classified as myopic.

\section{Produbanco}

Produbanco is a financial institution that emerged in 1978 in Ecuador, serving the corporate sector. Over the years, it has been expanding the business segments and the geographical area of activity, growing internationally. In 2014, the company joined the Promerica Group and they continue to work together. Considering that the mission is not presented on the website, in this case, the scope of action was not analyzed.

The company does not present its vision on the institutional website but exposes the core values and strategic objectives. Thus, Produbanco's core values are:

(1) To manage assets responsibly; (2) To grow in banks, means of payment, small and medium-sized companies; (3) To continue leading the corporate bank; (4) Being an omnichannel leader.

Moreover, the strategic objectives are:

(1) To focus on the customer; (2) To develop business by leveraging the relationship among market segments and deepening the relationship with customers; (3) To differentiate by innovation and technology; (4) To enhance the management of subsidiaries; (5) To position the brand's strengths and corporate image; (6) To capitalize the belonging to Promerica Group.

Therefore, Produbanco's strategic orientation is focused on the product (example: "growing in banks, means of payment, small and medium-sized companies"); to customers (examples: "focusing on the customer", "deepening customer relationships"); and also to the other stakeholders (example: "to enhance the management of subsidiaries"). In this regard, the company's strategic orientation does not fit myopia's types considered in this research.

As stated on the website, Produbanco acts with social responsibility:

Produbanco aims to contribute to the progress of people and companies. When we grant a loan, we are contributing a place. When we finance a small business, we are supporting job generating. Produbanco has a great responsibility, and the way of doing business implies financial inclusion.

Furthermore, Produbanco also annually declares the Social Responsibility Report and is committed to the UN Sustainable Development Goals. Thus, the relationship with the organizational environment is concerned with customers ("progress of people and companies"), with the market (when considering the impact that a loan and financing can have on society), and with other stakeholders (commitment to the environment). 


\section{Comparative analysis of the investigated companies}

It is adequate to confront the analysis of the investigated companies to detect possible similarities in the classifications of the analysis categories. Firstly, the scope of action was comparatively analyzed. Secondly, the strategic orientation. And finally, the relationship with the organizational environment. To examine the elements of analysis, we based on the marketing myopia literature to identify whether the companies are myopic (Levitt, 1960; Smith et al., 2010).

To analyze the (1) Scope of Action of the organizations, we observed the (i) definitions of products and their attributes and (ii) customers and their needs, since excessive concern only with products and customers might be the evidence of marketing myopia (Levitt, 1960). We also examined the (iii) definition of customers, stakeholders, and the needs of both, aiming to identify whether the company is new myopic free (Smith et al., 2010). Table 2 summarizes these analyses.

Table 2 - Comparative Analysis of the companies' scope of action

\begin{tabular}{l|l|l|l|l|l}
\hline $\begin{array}{l}\text { Elements of } \\
\text { Analysis }\end{array}$ & $\begin{array}{l}\text { Arcos } \\
\text { Dorados }\end{array}$ & Santander & Farmacorp & $\begin{array}{l}\text { Magazine } \\
\text { Luiza }\end{array}$ & Produbanco \\
\hline $\begin{array}{l}\text { (i) Definition of the } \\
\text { products and the } \\
\text { products' attributes }\end{array}$ & Food quality & Not defined & $\begin{array}{l}\text { What is } \\
\text { accessible to } \\
\text { few }\end{array}$ & $*$ \\
\hline $\begin{array}{l}\text { (ii) Definition of the } \\
\text { customers and their needs }\end{array}$ & $\begin{array}{l}\text { Everyone } \\
\text { [customers]; } \\
\text { their needs are } \\
\text { not defined }\end{array}$ & $\begin{array}{l}\text { People and businesses; } \\
\text { their needs are not } \\
\text { defined }\end{array}$ & $\begin{array}{l}\text { Families; their } \\
\text { needs are not } \\
\text { defined }\end{array}$ & $\begin{array}{l}\text { Many } \\
\text { [customers] }\end{array}$ & $*$ \\
\hline $\begin{array}{l}\text { Definition of } \\
\text { (iii) } \\
\text { customers, stakeholders, } \\
\text { and the needs of both }\end{array}$ & $\begin{array}{l}\text { [customers]; } \\
\text { other } \\
\text { stakeholders } \\
\text { are not } \\
\text { mentioned }\end{array}$ & $\begin{array}{l}\text { People and businesses } \\
\text { [customers and other } \\
\text { stakeholders]; their } \\
\text { needs are not defined } \\
\text { [customers]; } \\
\text { other } \\
\text { stakeholders not } \\
\text { are } \\
\text { mentioned not }\end{array}$ & $\begin{array}{l}\text { Many } \\
\text { [customers]; } \\
\text { other } \\
\text { stakeholders are } \\
\text { not mentioned }\end{array}$ & $*$ \\
\hline
\end{tabular}

Note: * Produbanco's scope of action was not analyzed because the information regarding the mission is not present on the website

Source: Authors

Thus, the only two companies with a broad definition of products and their attributes are Arcos Dorados and Magazine Luiza. Regarding the definition of customers and their needs, all investigated companies present broad definitions of the customers but do not identify their needs. These results show that, based on the self-declared objectives of the companies studied, these companies still do not prioritize or fully recognize the needs of their customers, according to Levitt's concerns regarding traditional myopia in marketing (Levitt, 1960). Finally, when analyzing the definition of customers, stakeholders, and the needs of both, only Santander has a definition of customers and stakeholders (but does not present their needs); the other companies only define their customers. Thus, according to Levitt's classification (1960), companies with the myopic scope are Santander and Farmacorp. The other companies are exempt from myopia in marketing.

The (2) Strategic Orientation of the companies was observed according to the (i) focus on the product, to identify the presence of myopia in marketing (Levitt, 1960). The analysis of the (ii) focus on the customer was adequate to examine whether the strategic orientation had a myopic focus (Levitt, 1960). Finally, we also analyze the (iii) focus on the customers and the stakeholders to classify the companies according to the Smith et al.' (2010) myopia in marketing. Table 3 presents this analysis category. 
Table 3 - Comparative Analysis of the Companies' Strategic Orientation

\begin{tabular}{l|l|l|l|l|l}
\hline $\begin{array}{l}\text { Elements of } \\
\text { Analysis }\end{array}$ & Arcos Dorados & Santander & Farmacorp & Magazine Luiza & Produbanco \\
\hline $\begin{array}{l}\text { (i) Focus on the } \\
\text { product }\end{array}$ & Best experience & - & $\begin{array}{l}\text { Smartphones, TVs, } \\
\text { computers }\end{array}$ & $\begin{array}{l}\text { Banks, means of } \\
\text { payments, and } \\
\text { corporative } \\
\text { banks }\end{array}$ \\
\hline $\begin{array}{l}\text { (ii) Focus on the } \\
\text { customers }\end{array}$ & Our people & $\begin{array}{l}\text { Customer- } \\
\text { oriented } \\
\text { business model } \\
\text { and values }\end{array}$ & $\begin{array}{l}\text { Best customer } \\
\text { service; values } \\
\text { focused on the } \\
\text { customers }\end{array}$ & $\begin{array}{l}\text { To make the } \\
\text { connected } \\
\text { appliances accessible } \\
\text { (customers digital } \\
\text { inclusion) }\end{array}$ & $\begin{array}{l}\text { Focus on the } \\
\text { customer; Deep } \\
\text { relationship with } \\
\text { the customers }\end{array}$ \\
\hline $\begin{array}{l}\text { (iii) Focus on the } \\
\text { customers } \\
\text { stakeholders and }\end{array}$ & $\begin{array}{l}\text { Our people; } \\
\text { shareholders }\end{array}$ & - & $\begin{array}{l}\text { Management of } \\
\text { the subsidiaries }\end{array}$ \\
\hline
\end{tabular}

Source: Authors

Among the companies considered, three present foci on the product: Arcos Dorados, Magazine Luiza, and Produbanco. Furthermore, the only companies that focus on the three elements of analysis were Arcos Dorados and Produbanco, configuring them as myopia-free. Similarly, Santander and Farmacorp have a single focus on the customer, classifying both strategic orientation as myopic according to Levitt (1960) and Smith et al. (2010). Magazine Luiza has its strategic orientation classified as myopic only from the perspective of Smith et al. (2010).

Regarding the (3) Relationship with the Organizational Environment, companies were analyzed according to three elements. Whether the companies presented (i) concern with the customer and the (ii) concern with the market, denotating a possible marketing myopia (Levitt, 1960). Moreover, if the companies presented (iii) concern with the multiple stakeholders, to identify the presence of the new marketing myopia (Smith et al., 2010). Table 4 sums up this analysis.

Table 4 - Comparative Analysis of the Relationship with the Organizational Environment

\begin{tabular}{|c|c|c|c|c|c|}
\hline $\begin{array}{l}\text { Elements of } \\
\text { Analysis }\end{array}$ & Arcos Dorados & Santander & Farmacorp & Magazine Luiza & Produbanco \\
\hline $\begin{array}{l}\text { (i) Concern for } \\
\text { customers }\end{array}$ & $\begin{array}{l}\text { Meeting customers' } \\
\text { quality of life needs, } \\
\text { etc. }\end{array}$ & $\begin{array}{l}\text { Socio- } \\
\text { environmental } \\
\text { risk analysis as a } \\
\text { criterion for client } \\
\text { acceptance, etc. }\end{array}$ & $*$ & $\begin{array}{l}\text { Comprehension of } \\
\text { the customer not } \\
\text { only as a consumer } \\
\text { but as an individual } \\
\text { with long-term } \\
\text { needs }\end{array}$ & $\begin{array}{l}\text { Progress of people } \\
\text { and companies }\end{array}$ \\
\hline $\begin{array}{l}\text { (ii) Concern with } \\
\text { the market }\end{array}$ & $\begin{array}{l}\text { Promotion of local } \\
\text { producers and } \\
\text { markets, etc. }\end{array}$ & $\begin{array}{l}\text { Commitment to } \\
\text { ethics and } \\
\text { sustainable } \\
\text { development, etc. }\end{array}$ & * & $\begin{array}{l}\text { Project } \\
\text { management in the } \\
\text { areas of culture, } \\
\text { sport, education, } \\
\text { etc. }\end{array}$ & $\begin{array}{l}\text { Consideration of } \\
\text { the impact of a } \\
\text { loan or financing } \\
\text { on society }\end{array}$ \\
\hline $\begin{array}{l}\text { (iii) Concern for } \\
\text { multiple } \\
\text { stakeholders }\end{array}$ & $\begin{array}{l}\text { Sustainable } \\
\text { practices adopted in } \\
\text { daily business, etc. }\end{array}$ & $\begin{array}{l}\begin{array}{l}\text { Promotion of } \\
\text { culture, sport, } \\
\text { education, etc. }\end{array}\end{array}$ & * & $\begin{array}{l}\text { Partnerships with } \\
\text { suppliers that } \\
\text { adopt sustainable } \\
\text { practices, etc. }\end{array}$ & $\begin{array}{l}\text { Social } \\
\text { Responsibility } \\
\text { Report, etc. }\end{array}$ \\
\hline
\end{tabular}

Note: * Farmacorp's relationship with the organizational environment was not analyzed because the information in this regard is not present on the website.

Source: Authors. 
Therefore, all companies demonstrate concern in some way with the three elements of analysis, denoting that none of them is classified as myopic regarding their relationships with the organizational environment. These findings show that, with few exceptions, the companies started to create goods and services focused on economic profit concomitant with concern for stakeholders' demands. These actions described in our study demonstrate that the companies responding to the alerts of a myopic vision towards the environment (e.g., Smith et al., 2020; Bernal, 2011; Yenicioglu \& Suerdem, 2015). After ten years of the discussion by Smith et al. (2010) regarding new myopia in marketing, our results evidence that the best South American companies for customers also declare a strategic orientation for their stakeholders.

\section{Final considerations}

This research sought to explore business strategies from the new marketing myopia perspective through the multiple case analysis. As a main finding, we demonstrated that the companies recognized as customer-oriented do not acknowledge other stakeholders' demands, considering the definition of the scope of action, strategic orientation, and relationship with the external environment. However, to indirectly address the other stakeholders' demands, the companies maintain a relationship with the organizational environment, carrying out actions that demonstrate concern for customers and other stakeholders.

From the perspective of the new marketing myopia suggested by Smith et al. (2010), the analyzed companies are not entirely exempt from this new type of myopia since they have difficulty establishing customers and stakeholders' demands when defining their business strategy. The new marketing myopia might be overcome when companies can shift from punctual actions - to maintain a good relationship with stakeholders - to a stage in which stakeholders' demands are incorporated into the scope of action (mission) and strategic orientation (vision, values). Marketers must act actively in defining the strategic plan, demonstrating to higher-level executives the long-term risks of not considering holistically the potential stakeholders have to transform the entire industry.

The contributions of this paper are two-fold. Firstly, as theoretical implications, this research expands the discussion initiated by Smith et al. (2010) by offering tangible elements in the companies' business strategies that may lead or prevent new myopia in marketing. Smith et al. (2010) define a company's basic assumptions as considered myopic from a new perspective, but do not offer elements that help researchers and professionals identify this new myopia. In this study, we help organize these elements: scope of action, strategic orientation, and relationship with the organizational environment. These elements can support future researchers to identify the new marketing myopia and relate it to marketing results.

Secondly, as practical implications, this study provides trails for marketers to recognize their actions under the new marketing myopia's philosophy. The marketing literature demonstrates that a company's mission and vision guide the entire administrative process (Sobral \& Peci, 2013). More than sixty years after Levitt's lesson (1960), this research indicates that companies still have difficulty overcoming myopia in marketing in its original sense, recognizing that overcoming the new marketing myopia is a relevant contemporary challenge in organizations. To overcome this challenge, marketers must think about the company's mission and vision while balancing both customers' and stakeholders' demands. The Santander and Magazine Luiza cases demonstrate how to conciliate both demands when establishing the mission and vision.

This research presents limitations. Firstly, we sought to analyze the elements of mission, vision, and strategic actions stated on the companies' websites because these elements provide a trail of the business strategy. However, an analysis of other documents and information provided in the media and taking a longitudinal perspective, such as the analysis carried out by Levitt (1960), could provide more details and 
more depth in the analysis of the companies. Future studies may apply more elements to identify the presence or absence of the new marketing myopia. Secondly, according to Freeman and Reed (1983), stakeholders are any group or individual that can affect or is affected by the company's objectives. Furthermore, companies need to consider that the market comprises stakeholders who identify offers that are not harmful to individuals or organizations (Bernal, 2017). Besides, consumers are increasingly concerned about the impacts generated by consumption, considering not exclusively their basic needs but ethical and environmental issues in their purchases (Prado \& Moraes, 2020). These aspects show that stakeholder demands are multifaceted and can generate numerous conflicts between different stakeholders over time. Thus, our analysis focused only on the declaration of companies does not account for all plural views of the stakeholders. Future studies should map all the stakeholders operating in a given economic sector and analyze how companies manage conflicts to have a competitive advantage, that is, ruled out concerns new marketing myopia. Lastly, we did not intend to establish a relationship between the new marketing myopia and the respective companies' failure in this study. Future studies may analyze the relationship between the presence or absence of the new marketing myopia with market performance.

\section{References}

Andrade, R. O. B. De, \& Amboni, N. (2010). Estratégias de gestão: processos e funções do administrador. Rio de Janeiro: Elsevier.

Andion, M. C., \& Fava, R. Planejamento estratégico. (2002). Coleção Gestão Empresarial, 2(3), 27-38. Available on: http://saude.riopreto.sp.gov.br/wiki/images/9/9e/Planejamento.pdf

Bernal, C. L. Gil. (2017). Marketing, su persistente miopia y la ausencia de su fundamento. (Monografia). Programa de Administração de Empresas - Universidad de La Salle, Bogotá. Available on: https://ciencia.lasalle.edu.co/administracion_de_empresas/1417/

Brennan, L., Previte, J., \& Fry, M.L. (2016). Social marketing's consumer myopia. Journal of Social Marketing, 6(3), 219-239. Doi: https://doi.org/10.1108/JSOCM-12-2015-0079

Campos, S.A.P, \& Pedroso, E.A. (2015). Criação de sentido através da prática da estratégia: a responsabilidade social corporativa como um processo contínuo e compartilhado, Reuna, 20(1), 73-98. Available on: http://revistas.una.br/index.php/reuna/article/view/620

Ceribeli, H.B., Maciel, G.N., \& Guilarducci, C.A. (2017). Competency management in Brazil: a multicase study. Reuna, 22(4), 20-39. Doi: http://dx.doi.org/10.21714/2179-8834/2017v22n4p20-39

Ciccarino, I., \& Araki, M. E. (2017). Blockchain como um fator de mudança na competição e no arranjo econômico de oportunidades. In Proceedings of the XX Semead. Available on: https://login.semead.com.br/20semead/anais/arquivos/2055.pdf

David, F.R. (2009). Strategic management: concepts and cases. 20 ed. New York: Pearson Prentice Hall.

Forbes. 9 empresas sul-americanas mais focadas no cliente. (2018). Available on: https://forbes.uol.com.br/listas/2018/12/9-empresas-sul-americanas-mais-focadas-no-cliente/

Freeman, R. E., \& Reed, D. L. (1983). Stockholders and Stakeholders: A new perspective on corporate governance. California Management Review, 25(3), 88-106. Doi: https://doi.org/10.2307\%2F41165018

Golijan, J., \& Dimitrijević, B. (2018). Global organic food market. Acta Agriculturae Serbica, 23(46), 125140. Available on: http://scindeks.ceon.rs/article.aspx?artid=0354-95421846125G

Hillebrand, N., Driessen, P.H., \& Koll, O. (2015). Stakeholder marketing: theoretical foundations and required capabilities. Journal of the Academy of Marketing Science, 43, 411-428. Available on: https://link.springer.com/article/10.1007/s11747-015-0424-y

Kull, A.J., Mena, J.A., \& Korschun, D. (2016). A resource-based view of stakeholder marketing. Journal of Business Research, 69, 5553-5560. Doi: https://doi.org/10.1016/j.jbusres.2016.03.063 
Kumar, V., Rahman, Z., \& Kazmi, A.A. Stakeholder identification and classification: a sustainability marketing perspective. (2016). Management Research Review, 39(1), 35-61. Doi: https://doi.org/10.1108/MRR-09-2013-0224

Kunkel, F. I. R., Ceretta, P. S., Perin, B. M. Da R., \& Menezes, N. D. de. Mensuração das relações de satisfação dos clientes de uma agência dos correios. (2012). Revista Gestão \& Tecnologia, 12(1), 176-201. Doi: https://doi.org/10.20397/2177-6652/2012.v12i1.381

Lee, H.J., \& Yun, Z.S. (2015). Consumers' perceptions of organic food attributes and cognitive and affective attitudes as determinants of their purchase intentions toward organic food. Food Quality and Preference, 39, 259-267. Doi: https://doi.org/10.1016/j.foodqual.2014.06.002

Levitt, T. (1960). The Marketing Myopia. Harvard Business Review, 38, 57-66.

Levitt, T. (2004). The Marketing Myopia. Harvard Business Review, 82(7), 88-99. Available on: http://125.22.40.134:8080/jspui/bitstream/123456789/4090/1/Marketing\%20Myopia\%20Article.pdf

Lyra, M. G., Gomes, R. C., \& Jacovine, L. A. G. (2009). O papel dos stakeholders na sustentabilidade da empresa: Contribuições para construção de um modelo de análise. Revista de Administração Contemporânea, 13, 39-52. Doi: http://dx.doi.org/10.1590/S1415-65552009000500004

McCrory, M.A., Harbaugh, A.G., Appeadu, S., \& Roberts, S.B. (2019). Fast-food offerings in the United States in 1986, 1991, and 2006 show large increases in food variety, portion size, dietary energy, and selected micronutrients. Journal of the Academy of Nutrition and Dietetics, 119(6). Doi: https://doi.org/10.1016/j.jand.2018.12.004

Oliveira, D.M.S., \& Luce, F.B. (2020). Is marketing department important for companies? Revista Pensamento Contemporâneo em Administração, 14(3). Doi: https://doi.org/10.12712/rpca.v14i3.41042

Pereira, F.C.M. (2018). Evaluation of the business environment for use of information in the definition of business strategies. Reuna, 23(3), 32-53. Doi: http://dx.doi.org/10.21714/2179-8834/2018v23n3p3253

Pereira, M. F., Schmitt, V., \& Caldas, A. de M. (2006). Visão, estratégia e execução: o caso da Gol. In Proceedings of III Simpósio de Excelência em Gestão e Tecnologia. Available on: https://www.aedb.br/seget/arquivos/artigos06/649_5\%20Artigo\%20GOL.pdf

Portella, A. R., Oliveira, M. C., Ferreira, D. D. M., \& Borba, J. A. (2015). Responsabilidade socioambiental por meio da missão, visão e valores: um estudo nas 100 maiores empresas de Santa Catarina. Revista Gestão e Sustentabilidade Ambiental, 4(1), 217-241. Doi: http://dx.doi.org/10.19177/rgsa.v4e12015217-241

Prado, N.B., \& Moraes, G.H.S.M. (2020). Environmental awareness, engaged consumption and organic products consumption. Revista Pensamento Contemporâneo em Administração, 14(2), 33-48. Doi: https://doi.org/10.12712/rpca.v14i2.42212

Smith, N. C., Drumwright, M. E., \& Gentille, M. C. (2010). The new marketing myopia. Journal of Public Policy \& Marketing, 29. Doi: https://doi.org/10.1509\%2Fjppm.29.1.4

Sobral, F., \& Peci, A. (2013). Administração: Teoria e prática no contexto brasileiro. 2. ed. São Paulo: Atlas. Urdan, A. T., \& Rocha, A. da. (2006). Orientação para o mercado: origens, avanços e perspectivas. Revista de Administração de Empresas, 46(2), 55-60. Available on: https://www.scielo.br/pdf/rae/v46n2/v46n2a06.pdf

Yenicioglu, B., \& Suerdem, A. (2015). Participatory New Product Development - A Framework for Deliberately Collaborative and Continuous Innovation Design. Procedia - Social and Behavioral Sciences, 195, 1443-1452. Doi: https://doi.org/10.1016/j.sbspro.2015.06.442

Yin, R. K. (2005). Case study: Planning and methods. 3th ed. Porto Alegre: Bookman. 